\title{
Designing process of a toothed segment of the KOMTRACK haulage system
}

\author{
Marek Kalita \\ Instytut Techniki Górniczej KOMAG, Poland
}

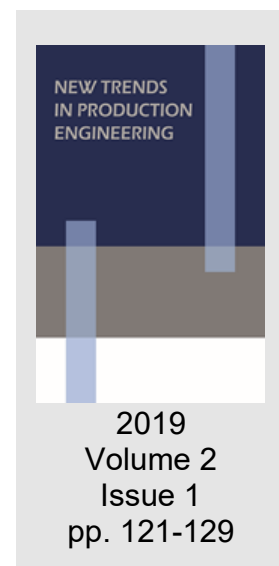

Date of submission to the Editor: 05/2019

Date of acceptance by the Editor: 07/2019

\section{INTRODUCTION}

A displacement of a shearer in a coal working is realized with use of a haulage system. A shearer haulage system consists of two kinematic pairs, i.e. driving toothed wheel installed In the shearer haulage units and the toothed bar located in the scraper - conveyor line pans. The most commonly used system is the chainless haulage system of the Eicotrack type. In this system the driving wheel makes the shearer move due to a repulsion from the pins of the haulage system toothed bar (Fig. 1) (Sikora et al., 2005, Zachura et al., 2015).
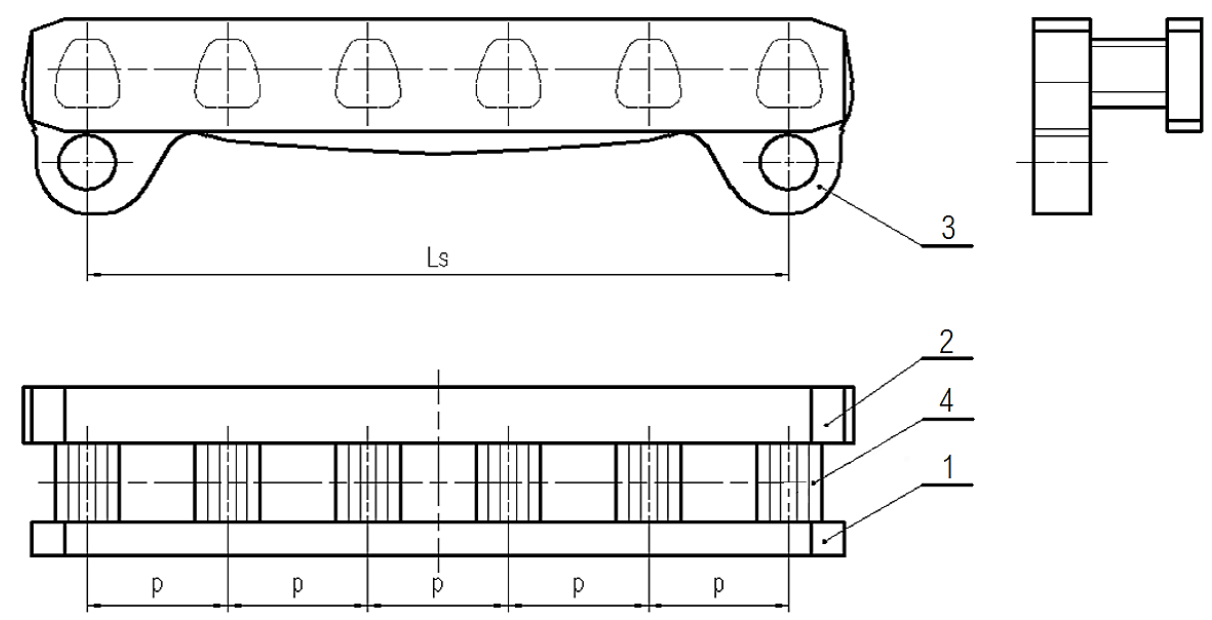

Fig. 1 Toothed bar of Eicotrack haulage system: 1 - narrow bar, 2 - wide bar, 3 - lug, 4 - pin Source: (Zachura and Żuczek, 2014)

In the result of the coal body cutting process a displacement of adjacent line pans of the conveyor occurs in the horizontal and vertical planes. Due to a stiff construction of the Eicotrack toothed bar system a change in a location of the driving toothed wheel in the relation to the toothed bars occurs. It causes a local change in the pitch of the extreme pins of the adjacent toothed bars and a change in distances of the pins of the toothed bar segments and axis of rotation of the driving wheel. Such an operation leads to so called edging of the teeth, 
which results in exceeding permissible clamping stresses occurring between the collaborating surfaces. Such a situation leads to a premature wear of the driving wheel and pins installed in the toothed bar. Besides, dynamic forces generated in the system, cause numerous break - downs resulting in financial losses due to down - time and replacement cost of damaged spare parts (Zachura, 2014). A solution, eliminating mentioned above, unwanted collaboration conditions of the described kinematic pair is an innovative longwall shearer haulage system with flexible toothed segments, developed at the KOMAG Institute, within the framework of the Flextrack project. The toothed segments installed in guides, replacing the Eicotrack toothed bar, enable a more advantageous collaboration of the shearer driving wheel, in particular in the case of the conveyor line - pan turning both in the vertical as well as the horizontal planes. The test results of the Flextrack system, conducted in laboratory conditions, have been used in the designing process of the toothed segments for the Komtrack haulage system to be used in highly productive longwall complexes.

\section{BASIC DESIGN ASSUMPTIONS}

One of the main reasons for undertaking research and development work connected with an elaboration of a new haulage system, to be used in highly productive longwall complexes, is an improvement of collaboration conditions of the kinematic pair: driving wheel - toothed bar. A new haulage system in relation to the Eicotrack system, used at present, should to a big extent, minimize a teeth edging phenomenon of the driving wheel occurring during scraper conveyor turns. Besides, a new haulage system should level the results of chain pitch disturbances due to a change in location of the axis of rotation of the driving wheel in relation to the haulage system toothed bar. The present knowledge of the design group, based on the results of the Flextrack project, indicates that a flexibility of the toothed bar pins, in relation to the rolling driving wheel, decreases a level of stresses generated during a longwall shearer displacement. The following assumptions were accepted for reaching the project objective:

- the maximal force carried by a tooth of the toothed bar segment is $500 \mathrm{kN}$,

- the angle of toothed bar turn in relation to each other is at least $+/-0.3 \mathrm{deg}$,

- values of stresses in each collaboration point of the frictional pair are below the material yield point,

- the shearer haulage system pitch is $151 \mathrm{~mm}$,

- the design of toothed bars levels the disturbances of the frictional pair pitch to maximal extent,

- a full exchangeability of the new shearer haulage units with the Eicotrack system used a present,

- a possibility of collaboration with driving toothed wheel of a longwall shearer. Basing on the project assumptions and on the Flextrack project results, the design group started to develop a construction form of a toothed segment adapted for a collaboration with the driving toothed wheel of a longwall shearer haulage unit. 


\section{DESIGN OF HAULAGE SYSTEM TOOTHED SEGMENT}

An individual toothed segment of a newly designed haulage system consists of a tooth and two side guides symmetrical in relation to the longitudinal plane. A correct collaboration of toothed segments requires modeling of contact planes and technological grips. Several computer analyses, aimed at a determination of a design form of collaboration planes and at shaping gripping elements of the toothed segment, have been conducted to achieve these objectives. In these analyses the proportions of the front and back parts of the gripping part of the toothed segment, in relation to the tooth overall dimensions, have been taken into consideration. The main parameters, describing a design form of the toothed segment side guides are shown in Fig. 2 .

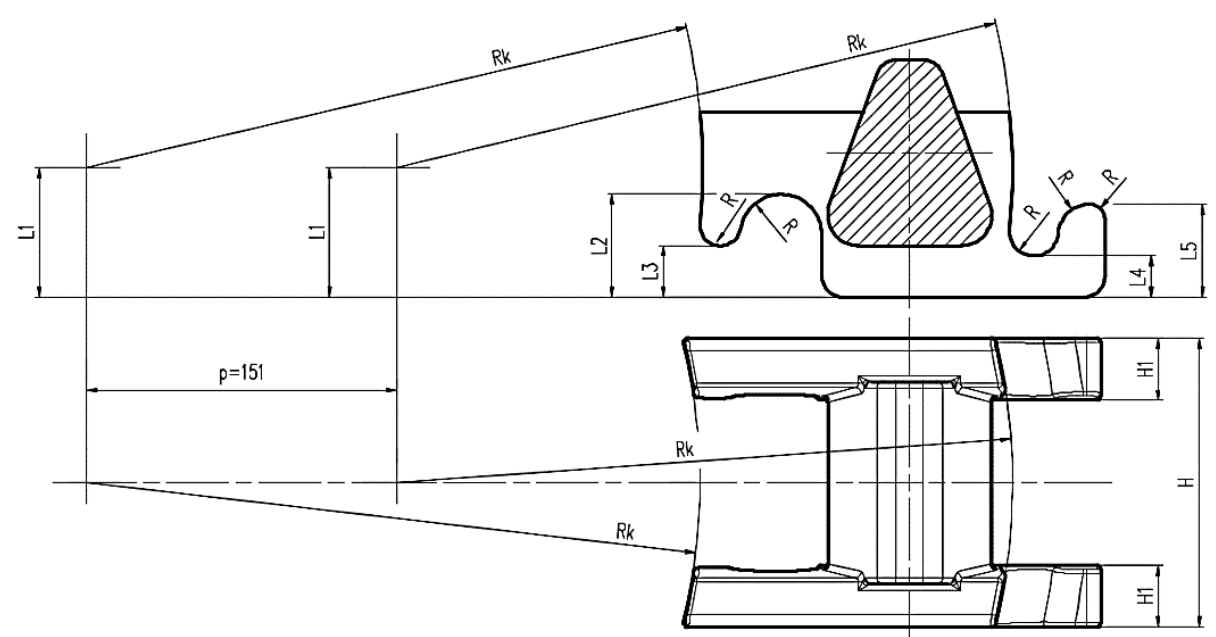

Fig. 2 Construction form of toothed segment side bars

The basic dimension, determining the geometry of the side guides is the $p$ pitch of the haulage system. The pitch and the L1 dimension define a location of the $\mathrm{Rk}$ radii, creating spherical surfaces in the toothed segment. The spherical surfaces enable a collaboration of the toothed segments situated in turn, creating the toothed bar of a shearer haulage system. One of the features, characterizing spherical ends of the toothed segment guides, is a possibility of an even distribution of loads generated by a shearer haulage force. Another feature of such shaping of a toothed segment is a possibility of toothed segments dislocation among them. Spherical surfaces enable a local change of the segment position (turn) in relation to the longwall system conveyor during a collaboration of the toothed segment with the driving wheel tooth. Such a functionality is essential in the case of scraper conveyor bends, in the longwall system, both in the vertical as well as in the horizontal planes. A flexibility of the toothed segment is a feature which distinguishes a newly designed solution in relation to chainless haulage systems of longwall shearers used at present.

It has been indispensable to design technological grips in the side guides for a correct assembly of the toothed segments and for maintenance operations of the toothed bar made of toothed segments.

The ends of the above mentioned grips in the haulage system perform different functions. The bottom grip does not carry any loads resulting from the longwall 
shearer haulage force. Its role consists in creating a possibility of the whole toothed bar displacement in the case of performing maintenance operations. The bottom grips, hooking on the lips in the top grips have a possibility of pulling the toothed segments installed in turn.

Then the top grip is an element which carries loads resulting from a collaboration with the driving wheel of the shearer haulage unit during its operation. Its frontal spherical surface collaborates with the spherical surface made in the back part of adjacent toothed segment.

Due to a possibility of carrying big loads it has been necessary to conduct an optimization of the construction form of grips in the aspect of getting as big frontal support as possible, at a simultaneous consideration of the bottom grip and of the tooth thickness. The conducted computer analyses enabled to determine the dimensions L2-L5 describing the geometry of the gripping and resistant parts of the toothed segment side guides. These surfaces have been ended with the $R$ radii to guarantee a manufacturing technology.

A construction form of the side guides should enable a correct operation of the teeth of the driving wheel which rolls over the following teeth of the toothed segments. Due to that the width of the driving wheel, a clearance ensuring a turning flexibility of the toothed segment and a possibility of carrying loads have been taken into consideration while determining the $\mathrm{H} 1$ width of the side guides. The determined $\mathrm{H} 1$ width of the guides and the tooth width enabled to determine the $\mathrm{H}$ width of the whole toothed segment.

The haulage force, generated by the shearer driving wheel, is carried directly by a tooth of the toothed segment. As it has already been mentioned, the thickness of the toothed segment tooth is closely connected with the geometry of the side guides and their gripping parts. After having determined the tooth thickness, it was possible to undertake design work concerning a determination of the geometry of the tooth profile outline. In the first stage two alternatives of the tooth outline of the driving wheel and of the toothed segment have been analyzed (Fig. 3).
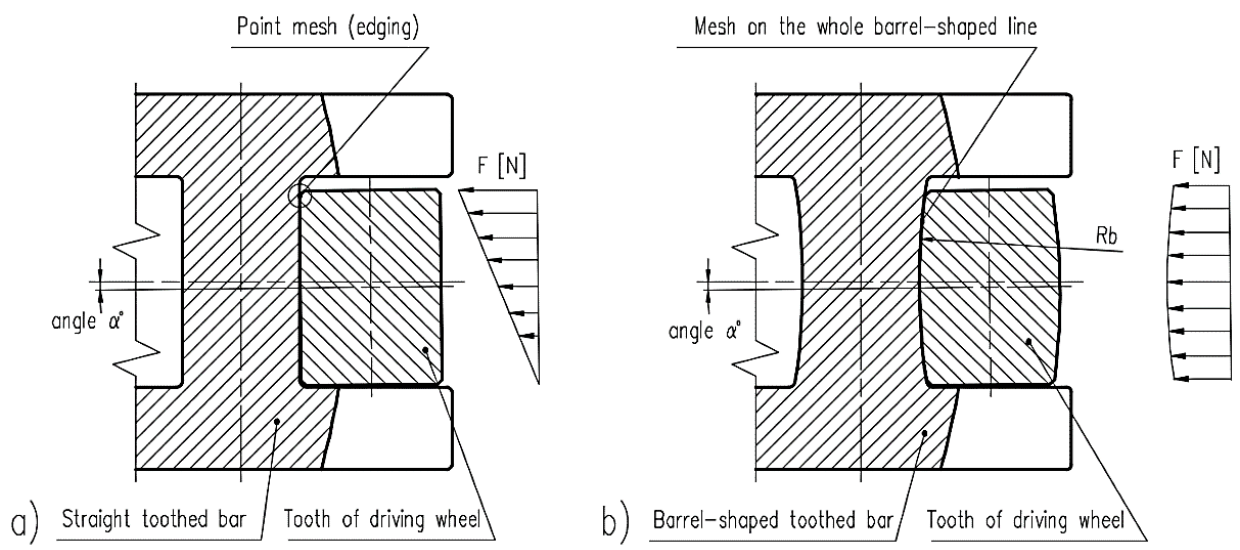

Fig. 3 Collaboration comparison of tooth profiles: a) straight, b) barrel-shaped

From the analysis of barrel teeth outlines it can be concluded that due to a possibility of turning the toothed segment tooth in relation to the driving wheel 
tooth by the a angle, a case of collaborating two barrel surfaces is more advantageous (Fig. 3b). In such a system loads are evenly distributed on the barrel - shape surface and thus the force is carried by the whole tooth. An angular disturbance of collaboration of the straight teeth outlines (Fig. 3a) leads to edging of the outlines and in consequence to point carrying of the loading force. In the result of teeth edging the values of clamping stresses between the collaborating surfaces of the frictional pair are exceeded. The design alternatives of the tooth outline have been taken into consideration in the following geometry analyses of the tooth profile outline. During design activities different profiles of the teeth outlines of the toothed segment have been analyzed (Fig. 4).
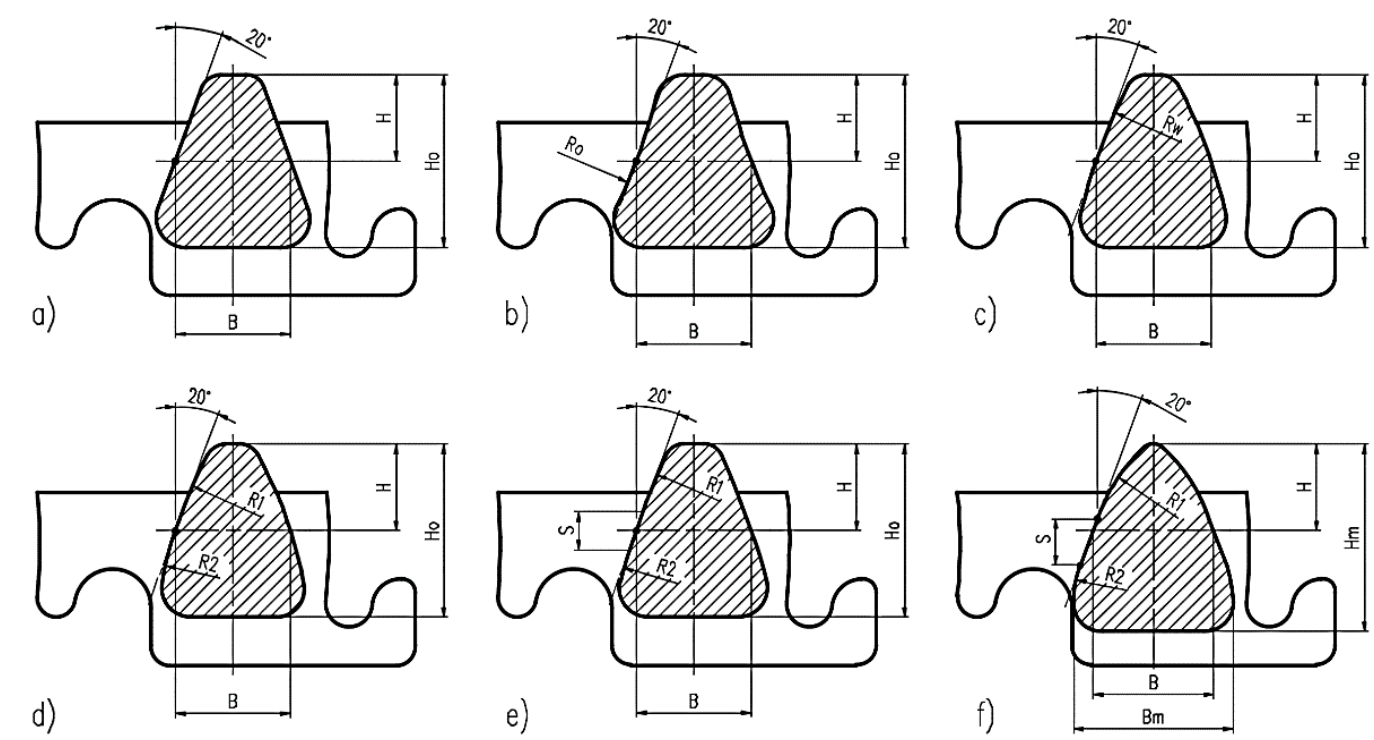

Fig. 4 Toothed bars of different teeth profiles: a) flat, trapezoid of $20^{\circ}$ wall inclination, b) concave with one curvature radius, c) convex with one curvature radius,

d) convex with two curvature radii, e) convex with two curvature radii and intermediate area, f) convex with flat intermediate area inclined at $20^{\circ}$ angle

The basic parameter, accepted in the designing process of a tooth profile, was the $20^{\circ}$ nominal pressure angle of the mesh. Each time while designing the following teeth profiles (Fig. 4a-e) the tooth width $\mathrm{B}$ on the nominal height $\mathrm{H}$ and the tooth height Ho were taken into consideration. During the conducted analyses different mesh version were designed: with flat, concave and convex profiles at different curvature radii. A tooth profile (Fig. 4f), different from the principles accepted in a construction of earlier profiles, was suggested. A tooth of the total width $\mathrm{Mm}$ and height $\mathrm{Hm}$, keeping the width $\mathrm{B}$ measured on the nominal height $\mathrm{H}$, was designed at a maximal use of the side guides width. For each version of the tooth profile, in the Autodesk Inventor environment, 3D models of a complete toothed segment, equipped with a tooth and two side guides (Fig. 5), were developed.

Each model of the toothed segments is characterized by the same side guides, in which on the base of earlier analyses, gripping parts and technological grips, were elaborated. The following versions of tooth profiles were modelled between guides. 
At the same time a strength verification, using the FEM method, of the 3D models of individual version, using the ANSYS software, was conducted. Identical boundary conditions, reflecting the degrees of freedom, occurring during a normal operation, were accepted in the calculations of all the toothed segments.

The external load, equal to the haulage force, was applied perpendicularly to the surface of the tooth profile in a form of the forces field, having an elliptical shape corresponding to the Hertz pressures, generated during a contact of the driving wheel with the surface of the toothed segment tooth. In relation to the tooth side which was loaded with force, the opposite side of the side guides made a support point on the spherical surfaces. Exemplary results of numerical analyses, in a form of maps of the von Misess's reduced stresses are given in Fig. 5.

a)

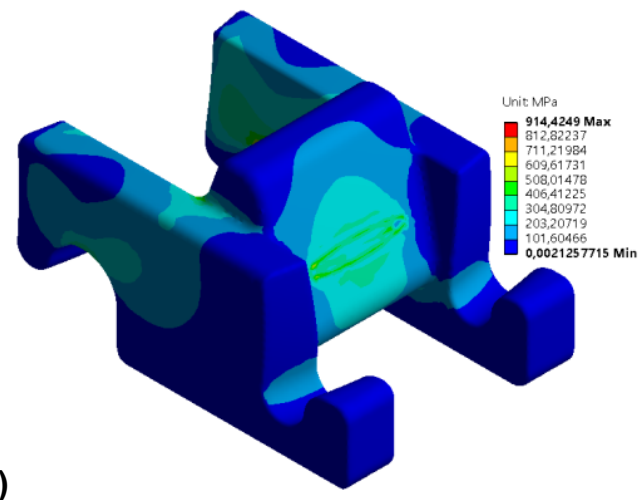

c)

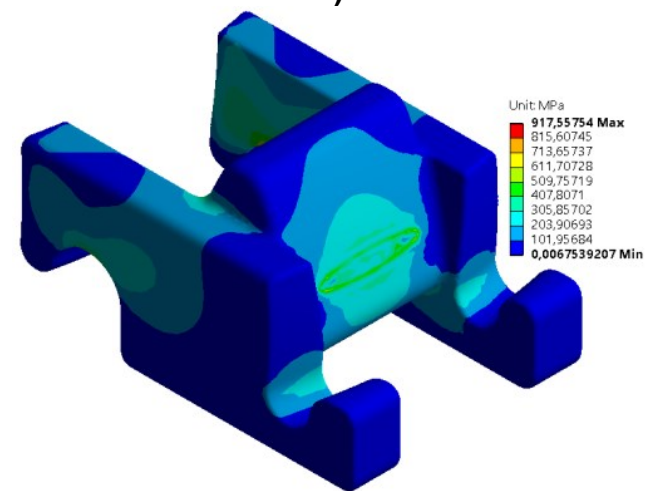

e)

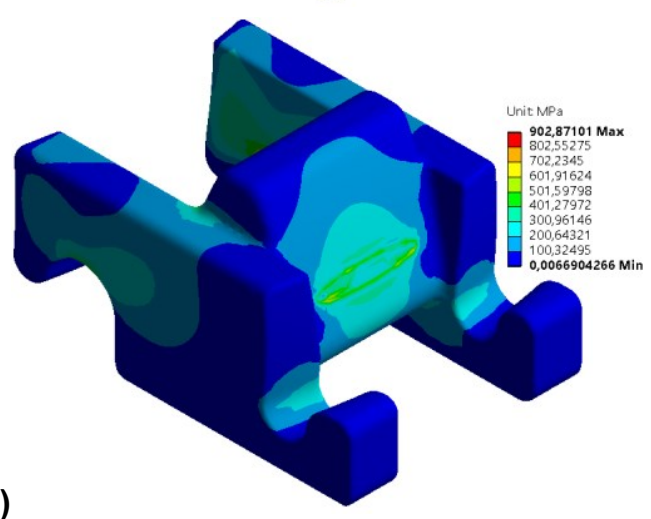

b)

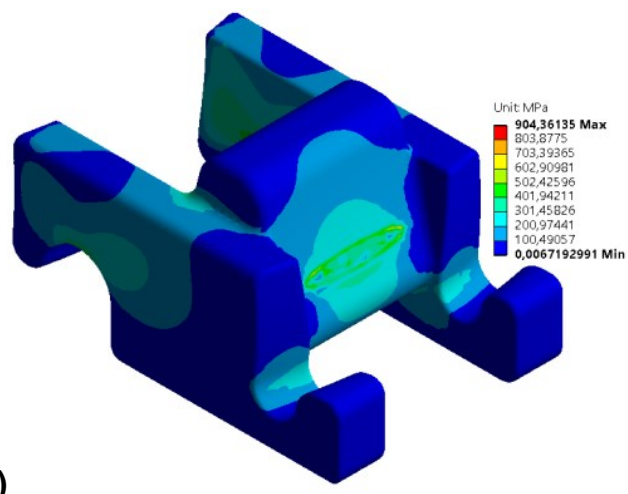

d)

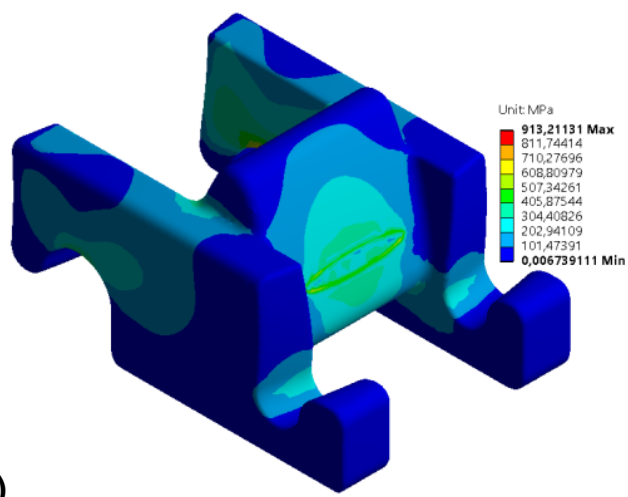

f)

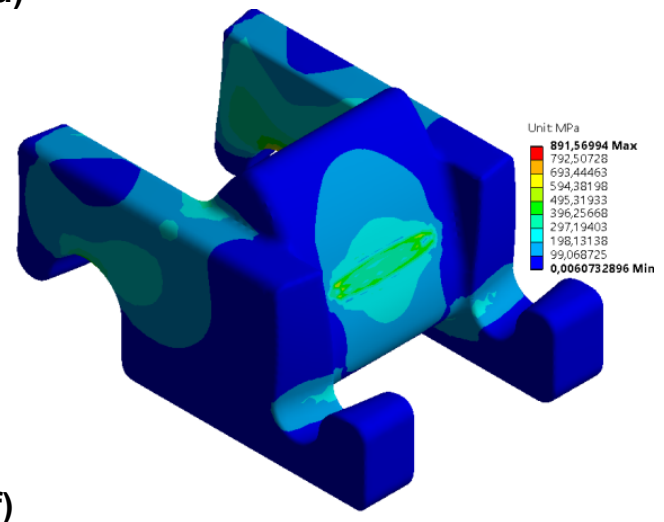

Fig. 5 Values of von Misess's reduced stresses for toothed bars:

a) flat, trapezoid of $20^{\circ}$ wall inclination, b) concave with one curvature radius,

c) convex with one curvature radius, d) convex with two curvature radii,

e) convex with two curvature radii and intermediate area,

f) convex with flat intermediate area inclined at $20^{\circ}$ angle 
Maximal values of the von Misess's reduced stresses for individual design versions of the toothed segments occur on a certain depth under the surface of a tooth profile - Bielajew's point (Fig. 6.).

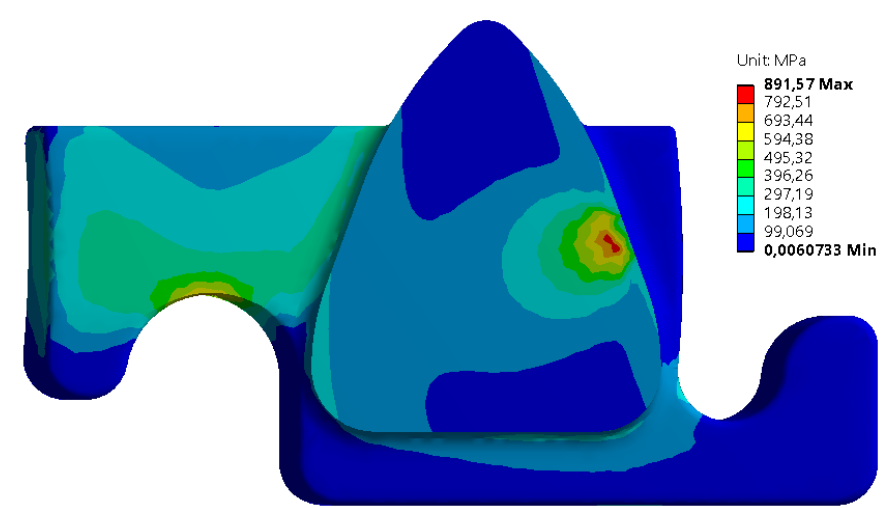

Fig. 6 Maximal values of reduced stresses - Bielayew's point

Values of stresses are given in Table 1.

Table 1 Values of von Misess's reduced stresses for individual design versions of toothed bars

\begin{tabular}{|l|c|c|}
\hline \multicolumn{1}{|c|}{ Toothed segment: } & Fig. 5 & Reduced stresses[MPa] \\
\hline Flat, trapezoid of $20^{\circ}$ wall inclination & a & 914 \\
\hline Concave with one curvature radius & b & 904 \\
\hline Convex with one curvature radius & c & 917 \\
\hline Convex with two curvature radii & d & 913 \\
\hline Convex with two curvature radii and intermediate area & e & 902 \\
\hline Convex with flat intermediate area inclined at $20^{\circ}$ angle & f & 891 \\
\hline
\end{tabular}

The loading force, applied to the surface of a tooth profile, causes a symmetrical distribution of stresses both in a tooth and in side guides.

The FEM strength calculations showed that the smallest values of stresses occur in the case of the toothed segment design (Fig. 5f), whose tooth profile is formed by two radii tangential to the straight segment situated in the middle part of the tooth.

The final design form of the toothed segment, being the result of the performed design work, is shown in Fig. 7.

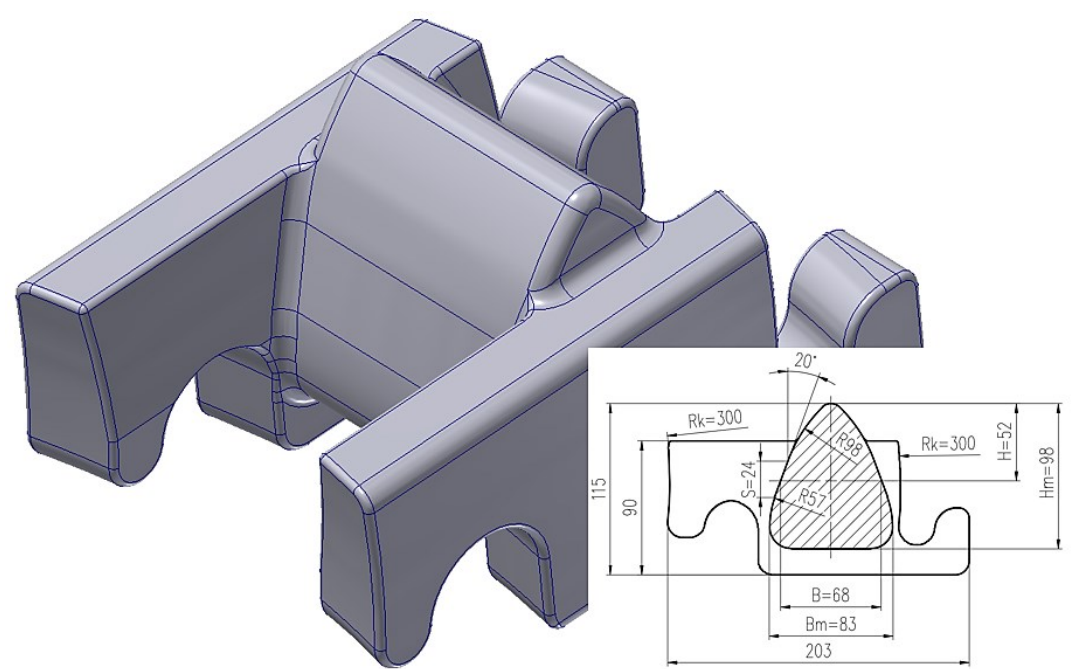

Fig. 7 Final design form of toothed segment for KOMTRACK haulage system 


\section{CONCLUSIONS}

The most important designing process stages of the toothed segment of the KOMTRACK haulage system, for use in highly productive longwall complexes, are presented in the article. The toothed path, composed of the following toothed segments, is to replace chainless haulage systems based on a stiff construction of the Eicotrack type toothed bar used at present. The main assumption, made for the needs of the design project realization, was a development of an innovative solution of a toothed segment characterized by a flexibility and a possibility of adopting turns of the conveyor used in a longwall system. Reaching this objective was possible due to a realization of multi - criterial geometric and kinematic analyses of the frictional pair: toothed bar tooth - driving wheel tooth. Different versions of side guides and of tooth profiles of the toothed segment were verified by the MES numerical analyses conducted on the base of 3D models. The criterion of maximal stresses was applied for a selection of the most advantageous design version. The calculations, taking into consideration identical boundary conditions for all the versions of the design form of the toothed segments, showed that the most advantageous solution of the toothed segment is the case of the profile composed of two radii tangential to the straight line situated in the middle of the tooth height.

Due to manufacturing reasons a use of barrel - shaped surfaces was given up in the design of the toothed segment. The conducted kinematic analyses of collaboration between the driving wheel with the toothed segments tooth show that the flexibility of the system does not cause teeth edging when nominal values of the turning angle of the frictional pair are kept.

Smaller values of stresses, than in the haulage system used at present, confirm the strength of the toothed segments. This feature has an impact on life and a longer period of a failure - free operation.

\section{REFERENCES}

Zachura A., Żuczek R. (2014) System posuwu Flextrack zwiększający trwałość i niezawodność napędu kombajnu ścianowego. W: Innowacyjne techniki i technologie dla górnictwa. Bezpieczeństwo - Efektywność - Niezawodność. KOMTECH 2014. Gliwice: ITG KOMAG, 2014, s. 151-161. ISBN 978-83-6070883-5

Sikora W. [red.] (2005). Obciążenia dynamiczne w układach ciągnienia wysoko wydajnych kombajnów ścianowych. Gliwice: Wydaw. Politechniki Śląskiej, ISBN 83-7335-299-6

Zachura A. et al. (2015). Flextrack - innowacyjny system posuwu kombajnu ścianowego, cz.2. W: Nowoczesne metody eksploatacji węgla i skał zwięzłych: monografia. Kraków: Wydaw. AGH, s. 195. ISBN 978- 83-930353-5-9

Zachura A. (2014) Quasi-statyczna analiza współpracy koła napędowego i zębatki w systemie posuwu kombajnu ścianowego. „Mechanik” 2014. R. 87, nr 10, s. 842848 


\section{Abstract.}

The following stages of a designing process of the toothed haulage segment are presented in the article. The toothed segment, developed within the framework of the KOMTRACK project, is an element of an innovative haulage system for highly productive longwall complexes. The project, according to the Contract No. POIR.04.01.04-00-0068/17, realized by the consortium: KOMAG, AGH University of Science and Technology, Foundry Institute, Specodlew Innovative Enterprise of Foundry Engineering, Ltd. and Polish Mining Group, J.S.C., is co-financed with the means of the European Regional Development Fund. The toothed bar, made of toothed segments of the haulage system, works together with the track wheel of a shearer haulage unit. A distinguishing feature of the newly designed haulage system, in relation to the system used at present, is its flexibility enabling individual toothed segments to adapt to longitudinal and transverse curvatures of the longwall conveyor track, which guarantees a correct cooperation with the track wheel.

Keywords: longwall system, shearer, shearer haulage system, toothed segment, gear wheel 